\title{
UMA VERSÃO CATÓLICA PARA A HISTÓRIA DO BRASIL NOS ANOS 1930
}

Itamar Freitas*

\begin{abstract}
RESUMO
Este artigo analisa a História do Brasil de Jonathas Serrano produzida no início dos anos 1930, momento em que a historiografia brasileira começava a ganhar um novo rumo com as publicações de Caio Prado Júnior, Gilberto Freyre e Sérgio Buarque de Holanda. O trabalho tem como objetivo proporcionar conhecimento sobre uma faceta da participação do ativista católico, escolanovista, professor de História do Colégio Pedro II e sócio do Instituto Histórico e Geográfico Brasileiro no processo de reinvenção da História como disciplina escolar para o curso secundário no Brasil.
\end{abstract}

PALAVRAS-CHAVE: História do Brasil. Jonathas Serrano. Ensino de História; Ensino secundário. Historiografia brasileira.

\begin{abstract}
This article analyzes the História do Brasil of the Jonathas Serrano produced at the beginning of years 1930, moment that the brazilian historiography started to gain a new route with publications of Caio Prado Júnior, Gilberto Freyre and Sérgio Buarque de Holanda. The work has as objective to give one aspect of the participation of the activist catholic, escolanovista, professor of History of the Colégio Pedro II and member of the Instituto Histórico e Geográfico Brasileiro
\end{abstract}

* Doutor em História da Educação (PUC-SP) e Professor do Departamento de Educação da Universidade Federal de Sergipe. 
in the process of reinvention History as a scholar discipline for the secondary course in Brazil.

KEYWORDS: History of Brazil. Jonathas Serrano. History Education. Secondary education. Brazilian historiography.

A década de 1930 é considerada um divisor de águas para a história da historiografia brasileira. Nessa época têm origem os primeiros cursos superiores de História. Também nesse período foram publicadas algumas das mais representativas sínteses sobre a experiência brasileira, tais como: a Evolução política do Brasil (1933), Casa grande e Senzala (1933) e Raízes do Brasil (1936). As condições de produção e o horizonte de expectativa dos seus autores legaramnos vários modelos historiográficos, conclusões sobre o passado e também sugestões para a resolução dos problemas que desafiavam a sociedade brasileira da primeira República. Cada uma dessas sínteses foi apresentada como inovadora no projeto para o Brasil, no modelo de inteligibilidade histórica e no método de exposição. Seus autores criticaram a escrita em voga, reivindicando uma história de tons culturais, sociais e econômicos; uma narrativa sobre o coletivo que tocasse no "íntimo" da experiência brasileira, que lhe descobrisse as estruturas. A crítica, entretanto, que tornou-se lugar comum entre os historiadores do século $X X$, quase extinguiu da memória do saber os demais projetos de escrita em vigor no início da década.

Esse artigo recupera uma dessas iniciativas, a História do Brasil (1931) de Jonathas Serrano, uma síntese que supostamente encarnaria alguns elementos historiográficos dos quais os herdeiros de Caio Prado Júnior, Gilberto Freyre e Sérgio Buarque de Holanda gostariam de se afastar. Com a análise dos seus conteúdos, buscase conhecer, não somente a participação do Jonathas Serrano escolanovista, historiador e professor de História do Colégio Pedro II na história da historiografia brasileira, mas também e, principalmente, a sua contribuição ao processo e invenção da História como disciplina escolar no Brasil.

Educ. e Filos., Uberlândia, v. 21, n. 42, p. 251-272, jul./dez. 2007. 
Jonathas Serrano ${ }^{1}$ já era professor de História do Colégio Pedro II quando publicou a sua obra História do Brasil (1931). ${ }^{2}$ No seu currículo estavam muitas monografias eruditas divulgadas na revista A Ordem e no periódico oficial do Instituto Histórico e Geográfico Brasileiro, e dois livros voltados para o público escolar: o Epítome de história universal (1913) e a Metodologia da história na aula primária (1917). O plano original, pensado desde 1919, recebera a colaboração da também educadora e historiadora Maria Junqueira Schmidt. ${ }^{3}$ Um projeto anunciado como original, certamente, que

1 Jonathas Serrano nasceu no Rio de Janeiro no dia 8 de maio de 1855, e morreu na mesma cidade, em 17 de outubro de 1944. Era filho de Frederico Guilherme de Souza Serrano - capitão de mar e guerra e senador da República - e de ED. Ignez da Silveira Serrano. (Cf. FALB, 1945, p. 77-80).

2 Os conteúdos de História do Brasil produzidos por Jonathas Serrano estão dispersos em notas de aula para o curso veiculado pelo rádio - “Universidade no Ar" - nos esboços de programas para o curso ginasial dos finais das décadas de 1920 e de 1930, e nos livros didáticos que publicou - História do Brasil (1931), Epítome de história do Brasil (1933) e História da civilização (1935/1937). A descrição e comentários que se seguem baseiam-se, entretanto, nas versões para os programas de [1929] e, majoritariamente, na História do Brasil de 1931. Além da fonte historiográfica, a História do Brasil de Serrano é também considerada significativa fonte sobre a História da disciplina escolar, já que é portadora dos "conteúdos explícitos" (cf. Chervel, 1990, p. 202-204). O exame sob o ponto de vista da produção de sentidos é tributário do modelo aplicado na obra Identidades do Brasil, de José Carlos Reis (1999). A abordagem historicista adotada dá a conhecer a forma de como Serrano manipula o passado, presente e o futuro dos brasileiros com vistas à um certo ideal pedagógico - a formação da personalidade integral do aluno, dentro de princípios virtuosos do cristianismo: o culto ao bem, ao belo e à verdade. (Cf. Freitas, 2006, p. 93).

3 Maria Junqueira Schmidt escreveu biografias sobre mulheres destacadas da nobreza "nacional": Amélia de Leuchtenberg, a segunda imperatriz do Brasil, e Princesa Maria da Glória, provavelmente publicadas entre 1928 e 1934. As obras mereceram a simpatia de João Ribeiro pelo estilo "fácil e ameno" e a raridade da temática: "tanto os nossos historiadores como os biógrafos deixaram na sombra os vultos dessas princesas e rainha que tanto influíram no Brasil e em Portugal. Nessa originalidade especializou-se D. Maria Junqueira Schmidt, de quem seria de esperar a tarefa (mais fácil, porém, mais curiosa) da vida de D. Carlota Joaquina, ou a de D. Tereza Cristina, a esposa do segundo Imperador, ou da Princesa Isabel, a redentora. Estaria assim completa essa galeria de 
trazia a experiência de anos de pesquisa arquivística, distribuída a conta-gotas durante as suas preleções. Entretanto, por mais que Serrano quisesse afastar-se da história militante e apologética contada por grande parte dos seus pares, ele não conseguiria, por certo, livrar-se de uma forma, talvez, particular à epistemologia do saber histórico erudito - e não somente escolar - dominante no seu próprio tempo: a narrativa. Sua história do Brasil tem começo, meio e fim, narrados - a bem dizer - a um só fôlego. A experiência dos brasileiros é organizada em perspectiva diacrônica, onde o final da história coincide com o resumidíssimo presente de Serrano - administração de Washington Luis - (1926/...). O início, por sua vez, desvenda o estabelecimento do Estado português (séculos XII e XV) e o progresso científico desse povo, evento e processo que possibilitaram os conhecidos ciclos de navegação e o conseqüente "descobrimento" do Brasil.

Numa primeira observação, pode-se perceber que o tempo é recortado à semelhança do programa ideal-típico de história do Brasil; o mesmo programa que resistiu ao projeto de Capistrano de Abreu em meados da década de 1880, e à "filosofia" de João Ribeiro, apresentada na História do Brasil de 1900. São trinta e nove segmentos mais ou menos regulares em termos de espaço que bem podem ser lidos (acompanhados) na mesma escansão fornecida pela vulgata de inspiração (inicialmente) varnhageneana, ou seja, no ritmo dado pela sucessão dos acontecimentos da política, sucessão conservada depois na tríade colônia-impériorepública. Entretanto, observados tais segmentos atentamente, pode-se localizar alguns assuntos que constrangem essa periodização e esse ritmo. Serrano inclui balanços que enfeixam o passado brasileiro de cem em cem anos. Assim, a periodização deixa de ser apenas colônia-império-república para tornar-se,

retratos femininos de maior relevo em nossa história. Os livros de Maria Junqueira são muito lidos e estimados pela delicadeza e simplicidade com que sabe desenvolver seus temas, naturalmente inspirados em profunda simpatia." (Ribeiro, Jornal do Brasil, 25 fev. 1928 e 23 mar. 1934, in: Leão, 1961).

Educ. e Filos., Uberlândia, v. 21, n. 42, p. 251-272, jul./dez. 2007. 
também, a pulsação regida por tempos simétricos: séculos XVI, XVII, XVIII, XIX e XX. ${ }^{4}$

Mas, que coisas se contam? Quais são os objetos privilegiados da sua história? Aqui, novamente a vulgata impera. São iniciativas de individualidades marcantes - Anchieta, D. João VI, Caxias; origem e legado de coletividades - das raças negra e indígena, da ordem jesuítica; empreendimentos de determinadas administrações - política interna do império, governos republicanos etc.; síntese do progresso da civilização brasileira em determinados níveis de experiência - na ciência, nas artes, na literatura (imperam a experiência política e a espiritual); e os fatos de curta duração invasões, revoltas, guerras, revolução, independência, abolição, proclamação da República. Esses dados são dispostos em linha reta. Os personagens são ordenados no evolver da nacionalidade, isto é, seguem percurso da ação política (algumas vezes, econômica) que se desloca da Bahia para Pernambuco, depois para São Paulo, Uruguai e Paraguai, São Paulo novamente, com Minas Gerais e Goiás, repousando, enfim, sobre o Rio de Janeiro, após rápidos passeios pelos movimentos insurgentes ocorridos no norte e no sul do Brasil. O plano de exposição é o "cronológico". Tal método, por sua natureza, incorre, obviamente, no abandono sucessivo de fatos e personagens situados à distância do centro geográfico de poder localizado, de início, na Bahia e depois, desde meados do século XVIII às três décadas do século XX, no Rio de Janeiro.

Personagens, empreendimentos e sua forma de disposição no tempo recortado por cinco séculos podem sugerir que a história do Brasil contada por Serrano tem como experiência privilegiada a ação política, a luta pelo poder - colonos versus jesuítas, reinois versus mamelucos, liberais versus conservadores, nacionalistas versus colonialistas etc. As ferramentas e os objetos utilizados na ordenação do passado dariam margem à conclusão de que a história do Brasil é a história da origem e consolidação do Estado

4 Isso não é gratuito. Mostraremos adiante a contribuição de cada século para a constituição progressiva da identidade brasileira. 
brasileiro independente. Mas não é exatamente isso que se deve concluir dos seus escritos. Está claro que não se pode apartar a política das questões do nacionalismo, identidade e autonomia. Também é perceptível que a dimensão economicista não interessa a Serrano: a cupidez, a ambição e a cobiça, notadamente no período colonial, são pecados condenados, tanto pelos religiosos do passado quanto pelo professor do século XX. Mas, o que efetivamente estrutura o movimento de personagens e o julgamento de suas ações é uma certa dimensão moral, ou melhor, a idéia de necessário e gradual aperfeiçoamento do brasileiro em direção ao padrão civilizatório. É o que se pode constatar no exame do conjunto das teses de cada capítulo. Sair da selvageria e do barbarismo significa adotar padrões morais avançados de comportamento em relação à religião, instrução, e à organização da sociedade via família, por exemplo.

\section{Produzindo sentidos para a história do Brasil}

Para Serrano, o Brasil do seu tempo - ele estende a história até 1928 - é um país que alcançou um "progresso bastante animador", no qual se podem depositar "grandes esperanças". O progresso pode ser constatado na intensificação da agricultura e da indústria, no aumento da população, do fluxo de imigrantes, da respeitabilidade no estrangeiro, no crescimento da produção literária e no pioneirismo em termos de instrução pública -"um dos primeiros do mundo a adotar oficialmente métodos mais modernos". (cf. SERRANO, 1931, p. 490). Nesse tópico, sem nomear, Serrano refere-se às reformas conduzidas sob a orientação de Fernando de Azevedo no município do Rio de Janeiro. É compreensível, portanto, que encerre a sua história do Brasil com um elogio à cidade, louvando-lhe a modernidade dos equipamentos urbanos: avenidas, ônibus, arranha-céus; e que registre o avanço do estilo arquitetônico importado dos Estados Unidos. Mas, de forma serena, também constata o surgimento de um "outro [estilo], genuinamente brasileiro, em plena florescência: o neo-colonial, que se foi definindo, precisando, e já tem hoje suas linhas próprias";

Educ. e Filos., Uberlândia, v. 21, n. 42, p. 251-272, jul./dez. 2007. 
esse o modelo arquitetônico adotado na construção das escolas municipais soerguidas no curso da reforma educacional de 1928.

Do que será o Brasil, portanto, ficam as pistas sobre a prosperidade econômica e literária e a positiva imagem da vitrine brasileira: "Estabeleceu-se um plano de embelezamento geral da cidade. Se esse plano chegar a ser executado, o Rio de Janeiro poderá ufanar-se de figurar entre as cidades mais belas do mundo, sob todos os pontos de vista." (SERRANO, 1931, p. 503). Mas, o que o Brasil foi? Como ele veio a constituir-se nesse espaço de esperanças? O Brasil foi palavra simplória, adensada de sentidos durante o século XVI. De adjetivo para o espécime vegetal, migrou para título de pátria, depois nação e país. O Brasil pátria ou a "pátria brasileira", fruto e sede do espírito de nacionalidade, nasce no século XVII. É aí que a "consciência" da "nova raça, oriunda da mestiçagem" aparece, sobretudo, quando luta sozinha (sem os portugueses natos) contra o "invasor" holandês, ou quando o paulista Amador Bueno se candidata "a chefe do país que se tornaria independente". A consciência de autonomia também é manifesta na língua, impregnada dos "vocábulos de além mar", na poesia do "reacionário" Gregório de Matos e no nativismo dos Emboabas e dos Mascates. (SERRANO, 1931, p. 214-215). O Brasil pátria nasce, portanto, do sentimento nativista. Mas, Serrano complementa:

O sentimento nativista apresenta no Brasil, como na Bélgica, e em outros países do mundo, a particularidade de ter nascido do sentimento religioso. A princípio, era a sua religião que o colono do Brasil defendia, lutando contra os calvinistas, franceses ou holandeses, e, depois ou talvez ao mesmo tempo, era a terra que já considerava sua que ele procurava conservar. Em seguida, fortificou-se o nativismo com o gosto das aventuras. O século XVII é o século das bandeiras; ora, os bandeirantes eram, na sua quase totalidade, brasileiros; tratavam, com orgulho e legitima vaidade, de encobrir aos portugueses as suas conquistas e suas descobertas. (SERRANO, 1931, p. 215). 
Também no século XVII, além das marcas na política, língua e literatura, nasce a "sociedade brasileira": fidalgos, escravos, mercantes e o clero. A "família brasileira" diferencia-se da família portuguesa: "não tem mais, é verdade, o sangue puro de alta linhagem de aristocracia fidalga dos centros urbanos, do século XVI. Substitui, porém, ao orgulho insensato e vão dos seus avós o amor ao trabalho; deles conservam 'o culto cavalheiresco da família e da honra'." (SERRANO, 1931, p. 216). Seus principais atributos, somente perdidos nos tempos de Serrano, seriam: hospitalidade, amor ao trabalho, apego à religião, à sua terra e à vida nos campos. Dos escravos, Serrano pouco fala nesse tópico. São mártires impotentes "da crueldade do fidalgo". Mas não se sabe se são negros e índios ou somente negros. Os mercantes - outra classe enriqueceram, "às vezes por casamento", e tenderão a subjugar a nobreza. O clero "simbolizava a instrução. Desfrutava bastante prestígio junto aos nobres. Exercia profunda, esclarecida e fecunda influência na vida nacional." (SERRANO, 1931, p. 217).

O século XVII marca o nascimento do Brasil pátria. E o que ficou para trás? Por que começar a história pelos rincões da Península Ibérica, quando Portugal nem se constituíra como Estado? Não há justificativas explícitas. A seqüência de assuntos indica uma hipótese. A volta ao século XII estabelece uma ligação importante para o futuro Brasil que é o seu caráter religioso (cristão) ${ }^{5} \mathrm{e}$ o aspecto positivo/progressista da metrópole que lhe transmitiria a "raça" e as principais orientações em termos civilizatórios.

Serrano também examina as origens indígenas, reconhecendo a sua contribuição para a raça brasileira: nos costumes, língua nacional, na luta contra estrangeiros. Mas, não há que romantizar

5 Observem a vinculação religiosa estabelecida no primeiro parágrafo sobre a história de Portugal: “Origens de Portugal - Primitivamente foi a península Ibérica habitada pelos celtíberos. A eles se mesclaram mais tarde fenícios, gregos, cartagineses, romanos, visigodos e árabes. Vencidos e confinados nos esconderijos das Astúrias, os cristãos retomaram, pouco a pouco, suas antigas possessões. Fundaram, então, vários, reinos, como os de Leão, Castela e Aragão." (SERRANO, 1931, p. 22-23).

Educ. e Filos., Uberlândia, v. 21, n. 42, p. 251-272, jul./dez. 2007. 
o seu "estado de civilização" no século XVI, como o fizeram José de Alencar e Gonçalves Dias. Poligamia, divórcio, infidelidade masculina no casamento, enfim, a antropofagia de parte deles não deixavam dúvidas sobre o seu "grau inferior de cultura". Por outro lado, também não há o que condenar, a exemplo de Frei Vicente do Salvador e Varnhagem: índios sem fé, lei e rei; índios sem crença alguma. Seus modos de vida são característicos dessa posição na escala de aperfeiçoamento humano. Quanto a isso, do que restou a fazer, os jesuítas deram mostras: catequese e instrução. Acrescente-se que essa necessidade de adaptação dos índios aos padrões brancos e o trabalho dos missionários católicos ainda valiam no tempo de Serrano. Pela Lei 3071, de $1^{\circ}$ de janeiro de 1916, os "silvícolas" eram considerados "relativamente incapazes" e, por isso, continuavam "sujeitos ao regime tutelar". (SERRANO, 1931, p. 61).

"O elemento africano" também é estudado em suas origens, lá na África. Serrano retroage até a idade antiga. Mas, o primeiro tópico frasal desse capítulo é duplamente indiciário. Ele demonstra a inferioridade civilizatória "dos negros" ou da "raça negra" e justifica o emprego dessa aviltante relação de trabalho em terras brasileiras: "A África sempre foi a terra da escravidão". Mas, como mensurar a posição da raça na escala de refinamentos? Simples! A África parou no tempo. "Pela civilização atual das tribos africanas pode o historiador depreender qual a índole, o caráter e o espírito da raça africana quando se transportou para o Brasil, em virtude da escravidão." (SERRANO, 1931, p. 166): tribos, patriarcalismo, vida em tendas, tosco mobiliário, comércio através de feiras, tempo contado em luas, literatura fundada em lendas e canções, fetichismo. Assim, diz Serrano, "em seu conjunto, apresenta a raça africana vários pontos de contato com o indígena brasileiro." Por consegüinte, para o mesmo problema, idêntico remédio: em pleno século XX, os missionários católicos na África cumprem função semelhante a dos jesuítas no Brasil em relação aos índios. Revela-se nessa comparação uma desvantagem adicional para os negros: eles não tiveram defensores no Brasil e raros foram os cronistas que registraram a sua experiência. 
Quanto "à influência" exercida na "formação do tipo brasileiro", o conceito é ambíguo. O negro já carregava as sementes da liberdade futura. Deu mostras de seu poder de organização no conflito de Palmares e, no "Brasil, encontrou o escravo africano a melhor de suas guaridas. Em menos de quatro séculos, incorporouse totalmente à nacionalidade brasileira." (SERRANO, 1931, p. 164). Esse poder de incorporação, esse ganho sob o ponto de vista "físico" e "moral" não apaga, porém, os episódios em que representou uma "ameaça para fazendeiros", perigo para as vilas; eram depredadores e vingativos (SERRANO, 1931, p. 172). Na verdade, entre negros e índios, Serrano afirma não saber quem entrou com a maior parcela de contribuição; há certeza de que ambos "retemperaram a raça branca e produziram, pelo caldeamento, uma população aclimatada ao novo meio"; e que a sua influência é perceptível nas gentes das classes "menos favorecidas". (SERRANO, 1931, p. 173). No final da síntese, a exposição vacilante sobre a situação do negro no Brasil da década de 1920 explicita a dificuldade de conciliar legados e responsabilidades: "A raça negra, aliás, não é uma raça inferior, e sim uma raça inferiorizada em conseqüência de seu longo cativeiro." (SERRANO, 1931, p. 164, grifo do autor).

Voltemos agora à síntese da evolução do país, pátria ou nação brasileiros. O século XVI, das origens metropolitana e nativa das raças formadoras do Brasil, é um "século de incertezas": na forma administrativa, tipo racial, direção comercial, produção literária e espírito patriótico dos colonos. O século XVII, já vimos, é o berço do Brasil, onde nascem a sociedade e o sentimento de pertença comum. O próximo intervalo, o XVIII, é "o século do ouro", da riqueza e também do orgulho dos colonos, da fome fiscal da metrópole e da conseqüente revolta dos brasileiros com o insaciável apetite da coroa. Nesse tempo, progride o comércio e a literatura, e espraia-se por todo o país "um espírito de povo que aspira a ser nação" (SERRANO, 1931, p. 262). No século XIX, realizam-se todas as emancipações: comercial (1808), política (1822) e literária (1836). D. João VI, D. Pedro I, D. Pedro II, Caxias e Mauá, entre outros, constroem o edifício político-administrativo-econômico e o Brasil

Educ. e Filos., Uberlândia, v. 21, n. 42, p. 251-272, jul./dez. 2007. 
pode, enfim, governar a si mesmo, estabelecendo as condições para o "progresso" "animador" que se verificará nas três primeiras décadas do século $X X$. O século $X X$, entretanto, só tem futuro. Escritos os textos no final dos anos 1920, não há espaço e ambiente de isenção (e, talvez, nem vontade de Serrano) para tratar de forma detalhada os acontecimentos políticos e literários desse tempo; tempo dos mais agitados e dos mais ricos em termos de idéias e projetos para a nação.

Para construir essa imagem positiva do Brasil, Serrano não se ancora numa corrente historiográfica em particular. Segundo conveniências e modos próprios descritos acima, serve-se, por exemplo, dos historiadores portugueses para afirmar a primazia lusitana no descobrimento do Brasil; de Varnhagem e do seu plano de redação da História geral do Brasil; de João Ribeiro para tipificar o sistema de capitanias hereditárias; Capistrano de Abreu para tratar do século XVII; de Rocha Pombo para afirmar a expansão do espírito de brasilidade; Oliveira Viana e a caracterização da sociedade branca brasileira; de Euclides da Cunha para a interpretação cientificista do fenômeno Canudos; de Ronald de Carvalho para descrever os caminhos da literatura brasileira; de Tobias Monteiro e Joaquim Nabuco para tratar de política e economia no século XIX. A sua história do Brasil também incorpora muitos dos seus trabalhos de erudição, lá estão os textos biográficos sobre José Martin, partícipe da Revolução de 1817, Felipe dos Santos, "o precursor de Tiradentes", e sobre José de Anchieta.

Com esse inventário de fragmentos de vários explicadores do Brasil, com essa síntese produzida no balanço de cinco séculos, algumas constâncias são destacáveis. A narrativa da história do Brasil revela-se por uma necessidade: o a priori da autonomia. A República é a forma política ideal. Ela nasce, cresce e floresce nesse percurso. O Brasil assemelha-se a uma semente extraída da Europa que germina em solo íngreme, com insumos de duvidosa qualidade, mas que tem o direito a um lugar no concerto das nações (raramente trata-se de povo brasileiro ou povos do mundo). O Brasil se esforça bastante para reduzir o desnível, a desproporção, o atraso em termos de escala civilizatória. O mesmo sentido da forma 
republicana de governo é obedecido pela literatura brasileira e pode também ser localizado no cultivo de sentimentos como o pacifismo, e na moralização dos costumes que purificarão as instituições políticas e sociais. Na história de Serrano, do século XIX em diante, o Brasil é quase como um fruto dos próprios esforços dos brasileiros.

\section{Os desvios da vulgata histórica de Serrano}

O "outro" do Brasil, em suma, não é sistematicamente os EUA, a Argentina ou o Paraguai, podem ser os EUA, a Argentina ou o Paraguai quando ele nota, por exemplo, que a relação entre raças ou a atitude de determinados líderes revolucionários foram mais odientas nesses países que no Brasil. O "outro" do Brasil, a relação de alteridade produzida pela história do Brasil de Serrano, todavia, não está nas grandes conclusões, nas sínteses de cada século, nos grandes sentidos descritos acima. Ele se revela muito mais nas pequenas intrusões, ou seja, naqueles momentos em que se abandona o foco narrativo em terceira pessoa, chamando o (inadvertido) leitor para o tempo presente. Dito de outra forma, o "outro" do Brasil - o que o Brasil não pode ser, em que o Brasil não se pode transformar e do qual Serrano luta para distanciar-se está no próprio Brasil de 1929/1930, em partes da vulgata histórica apresentada pelos livros didáticos e programas para o secundário.

Sobre os programas, pode-se notar o estabelecimento de um quase cânon de assuntos no período da reforma Benjamim Constant (1892), às vésperas da reforma Francisco Campos (1892/ 1929). Descontadas as modificações dos marcos temporais finais: Guerra do Paraguai (1892), República (1912), Governo Artur Bernardes (1926), e as variações de quantidade de pontos/aulas/ lições, o que se vê é a experiência brasileira prescrita no périplo colônia/império, contemplando os seguintes assuntos: descobrimentos portugueses, principalmente o do Brasil; índios; capitanias hereditárias; governos gerais; divisão e unificação dos governos; presença holandesa; conflitos entre jesuítas e colonos Revolta Beckman; conflitos em Palmares, dos Mascates e dos Emboabas; Guerras no sul - Espanha e tratado de Ultrech; o Brasil

Educ. e Filos., Uberlândia, v. 21, n. 42, p. 251-272, jul./dez. 2007. 
no tempo de D. João V; D. José, Pombal e a expulsão dos jesuítas. A chegada da Família imperial ao Rio de Janeiro; franceses, espanhóis e Revolução de Pernambuco; Revolução do Porto; D. Pedro I, dia do Fico, Independência; Constituinte, Aclamação e Abdicação; Regências, ação de Pedro II, Pacificação, Guerra do Paraguai e República completam o rol dos conteúdos.

Algumas mudanças pontuais, certamente, ocorreram ao longo desses trinta e sete anos. As alterações, em sua maioria, consistiram em desdobramentos de um ponto ou de reagrupamento de alguns assuntos, motivados pelas oscilações em termos de tempo semanal e localização no currículo. Assim, em 1898, a ação dos exploradores Cristóvão Jacques e Martim Afonso de Souza ganhou espaço em relação aos "primeiros exploradores" do programa de 1892. Os "índios" (1892) desapareceram do programa de 1912. Em 1915, os "descobrimentos" e as "explorações" foram fundidas; em 1926, reaparecesseram os tópicos "Revolução de 1817" e "Guerra do Paraguai". A história da República (1912), por sua vez, tem o espaço ampliado e já se esboça uma periodização para essa época - governo provisório, Constituição e governos constitucionais (1926). Outro tipo de mudança flagrada, que pode sugerir nova abordagem, foi a alteração dos títulos. "As primeiras idéias de independência" e "Tiradentes" (1892) foram nomeadas como "Inconfidência Mineira" (1915); "imigração dos Braganças" transformou-se em "transmigração da família real portuguesa D. João VI" (1915), e o assunto "índio" (1892) passou a "íncola" (1926). No que diz respeito à introdução de novos temas ou personagens é preciso fazer o registro da entrada do assunto "abolição" (1915).

O que estaria faltando nessa vulgata, para Serrano? O que deveria ser alterado? Inicialmente, dever-se-ia separar a aventura do descobrimento do estudo sobre o índio. O estudo do "estado de civilização" merece descrição e comentário mais alongado, afinal, trata-se de um dos elementos formadores do Brasil. Do mesmo modo que os índios, "O elemento africano" ganha espaço autônomo, disposto imediatamente após as invasões holandesas. Assim, o evento "Palmares", que se costumava descrever nos 
programas como um movimento de reação com a mesma estatura de Emboabas e Mascates, passou a ganhar sentido dentro do estudo sobre a organização social, usos e costumes, crenças, tráfico, cativeiro no Brasil e "influência da raça negra". O questionário assemelhava-se àquele aplicado a "O indígena brasileiro": "O homem da Lagoa Santa; as raças americanas"; principais grupos; distribuição geográfica das tribos; “[...] estado de civilização; organização da família; a guerra; as armas; os prisioneiros; crenças religiosas; lendas e tradições, população indígena; sua incorporação;" e, suas lendas. (SERRANO, 1931, p. 45).

Não somente as raças fundadoras foram emancipadas como assuntos. A "Colonização do Norte" separou-se do tema "Domínio espanhol, franceses no Maranhão, colonização do Norte" (1926) e passou a detalhar a experiência das conquistas da Paraíba, Sergipe, Rio Grande do Norte, Ceará, Piauí e Amazonas. As "Bandeiras", que estavam atreladas ao ponto/lição "Brasil no reinado de D. João V", transformaram-se em "Entradas e Bandeiras". Com isso, nota-se a ascensão do assunto "Entradas" (iniciativa oficial de expansão territorial), inexistente nos programas até então. $\mathrm{O}$ mesmo processo de partição e expansão ocorre com as "Lutas entre jesuítas e colonos, Beckman, Palmares, Emboabas e Mascates" (1926), abordados agora como "Lutas entre jesuítas e colonos" e "Lutas [dos jesuítas] com os colonos do Norte"; transmigração da família real portuguesa para o Brasil, D. João VI, Revolução de 1917", transforma-se em “D. João VI no Brasil" e "Revolução Republicana de 1817"; e, por fim, "A maioridade, Lutas civis até 1848, Lutas no Prata, Oribe e Rosas", passa a ser distribuído em parte do capítulo sobre a "Regência" e em "Caxias e a unidade do Império" e "A política exterior e as lutas no Prata".

Outra modificação relevante foi a inclusão de novos temas. Sobre os capítulos sintéticos - "O século XVI", "O século XVII" [...] - já tratamos. Eles descreviam as principais ocorrências de cada período, tipificando o valor da época para a configuração do Brasil nação. Mas, outros acréscimos existiram, como a introdução de um capítulo sobre a formação do Estado português - também comentado aqui - e uma "Nota liminar" sobre os autores e as formas

Educ. e Filos., Uberlândia, v. 21, n. 42, p. 251-272, jul./dez. 2007. 
de escrita da história do Brasil, o valor do estudo da história em ambiente escolar.

Teorizar sobre história não era nenhuma novidade em 1929, pois, a propedêutica do saber constava na introdução dos livros de história universal e também do didático da matéria, ainda no final do século XIX. Mas, teorizar sobre a escrita da história do Brasil é algo que pode ser considerado como inovador, haja vista que a história da historiografia não existia como disciplina escolar do secundário, do superior, ou mesmo como matéria erudita. $\mathrm{O}$ referido capítulo não era um estudo demolidor da historiografia dos séculos anteriores. Seu texto pode bem ser classificado como de "empenho historiográfico". ${ }^{6}$ Mas, era suficiente para informar ao leitor sobre as limitações do ofício, os responsáveis e as principais mudanças ocorridas em cento e cinqüenta anos, ou seja, para instrumentalizar esse mesmo leitor com vistas à crítica do próprio trabalho de Serrano e dos seus pares.

A introdução de novos capítulos pode reforçar o sentido da vulgata dos programas como ocorre em relação ao tema "Política interna do Império". Nesse segmento, que enfoca a vida partidária do momento da "conciliação", a era Mauá e a "questão religiosa" e a idéia de progresso desencadeado pelos acertos da política imperial são bastante enfatizadas. A entronização de novos temas, entretanto, pode modificar os tons dessa mesma vulgata e são exemplos marcantes o tratamento da revolta de Vila Rica e da ação dos jesuítas. "A revolta de 1720" conta a história dos sublevados de Minas liderados por Felipe dos Santos. Para Serrano, o evento fora motivado, principalmente, pela "[...]ambição excitada pelo ouro[...] o rigor crescente do fisco, as prepotências dos

6 Para Rogério Forastieri da Silva, “[...] podemos considerar o estudo historiográfico como o estudo da história dos escritos históricos, métodos, interpretações e as respectivas controvérsias. Como um setor autônomo do conhecimento, podemos localizá-lo no início do século XX. Entretanto os empenhos historiográficos, ou seja, uma preocupação propriamente historiográfica existe, pode-se afirmar, antes mesmo da existência dos estudos historiográficos produzidos com esta finalidade." (SILVA, 2001, p. 26) 
funcionários da Coroa, os monopólios, os estancos, as medidas odiosas, a carestia geral que então angustiou as opulentas regiões mineiras." (SERRANO, 1931, p. 41). Com essa inclusão, a experiência republicana de Tiradentes não mais vigoraria solitária. Há um valioso antecedente, que foi a ação Felipe dos Santos.

Quanto à experiência jesuítica, o desvio é bem maior: Serrano transforma em capítulo o que não se havia anunciado como título de tema desde 1892. "Os jesuítas" ganham espaço na história do Brasil colônia, justo entre a experiência dos governos gerais e o período da dominação holandesa. Mas, por que tanto prestígio para a ordem? Serrano justifica:

Com o seu sistema de catequese fizeram os jesuítas pelo Brasil mais do que todos os governadores e colonos que Portugal nos enviou [...] espalhando entre os nossos selvagens a semente da religião e ensinando as verdades austeras da moral no meio desregrado dos colonos, foram os jesuítas os primeiros mestres da mocidade americana e o mais importante dos elementos que concorreram para a formação do Brasil." (SERRANO, 1931, p. 104 e 102, grifos meus).

Tal proeminência - destronando colonos portugueses (funcionários e degredados entre outros), raças negra e indígena justificaria, mais adiante, o desaparecimento de "D. José I" e do "Marquês de Pombal" como título de segmento, presente nos programas desde 1892 até 1929 e inseridos no tópico final do capítulo "Os tratados de limites e a expulsão dos jesuítas". A expulsão dos jesuítas e o conseqüente desmonte do aparelho educacional e da formação intelectual, e a destruição dos escritos loiolistas levam Serrano à conclusão de que "[...] os males que nos fez Pombal excederam aos bens por ele operados em nossa pátria." (SERRANO, 1931, p. 263). Para que então um D. José e seu Marquês de Pombal encabeçando positivamente um período da história do Brasil?

As alterações até aqui relacionadas, por certo, serviram para fornecer maior visibilidade às ocorrências do Norte e do Sul do 
Brasil, estimulando o estudo sobre histórias regionais. A inversão de prioridades (os jesuítas em lugar de Pombal e de D. José), a valorização-identificação das raças originárias do Brasil, as pausassíntese proporcionadas pela inserção de capítulos enfeixando a experiência de cada século, tudo isso significa tentativas de modificação na vulgata dos programas de história do Brasil. Elas, contudo, não alteram radicalmente a estrutura da história do Brasil. Não são fundantes, reestruturadoras ou revolucionárias, nem mesmo em relação ao tempo de João Ribeiro e da sua História do Brasil, produzida três décadas antes; não são os cinco aglomerados, cada um com características próprias, que dão origem ao Brasil que se conhecia no início do século XX (cf. RIBEIRO, 1912). Serrano recupera a proposta de Varnhagem do contato entre povos de graus civilizatórios diferenciados, ou melhor, os inferiores progridem quando são postos em contato com os superiores. Com inspiração fundada em leituras de Spencer, talvez, a história do Brasil percorre itinerário marcado pelo processo civilizador - a estrada do aperfeiçoamento - capitaneado pelos povos e instituições que vieram da Europa (Serrano não registra "raça branca").

Vistas em conjunto, as incorporações contidas na História do Brasil (1931) revolucionam em outro sentido. Elas são fruto de atualização historiográfica do historiador Jonathas Serrano que reintroduziu alguns temas e teses de Capistrano de Abreu e de João Ribeiro, o resultado de pesquisas etnográficas do Museu Nacional, o sumo das suas investigações sobre Felipe dos Santos e José Martins, dando assim maior peso à experiência republicana brasileira. As alterações inseridas na História também demonstram o compromisso de Serrano com a proporção e a simetria no momento de seleção e distribuição dos assuntos no espaço-tempo (nas páginas do livro) de cinco séculos. Cobrir lacunas temporais, equilibrar no espaço-texto a experiência coletiva de raças, classes sociais, partidos políticos com a experiência das individualidades marcantes é também lição de objetividade, método, enfim, de ciência.

As alterações citadas abrem possibilidades para as experiências de professores atentos e responsáveis, bons ledores da historiografia 
e de pedagogia, comprometidos com a formação da personalidade do adolescente. O mesmo já não se pode afirmar sobre as raras intrusões de Serrano. Raras, mas significativas, porque deliberadamente doutrinadoras. ${ }^{7}$ Vejamos quatro delas:

Conseqüências da dominação holandesa - Se vencesse a Holanda, no conflito com Portugal, duas, pelo menos, teriam sido as desvantagens para o Brasil: primeiro, quebraria a unidade de religião, o que traria guerras religiosas fatais e inevitáveis; segundo, exporia o Brasil ao atraso em que jazem até hoje as colônias neerlandesas, pois a Holanda é um país essencialmente comercial e mercantil. (SERRANO, 1931, p. 159).

O exemplo que se segue não é autógrafo. Serrano o incorpora como paráfrase, mas dá a noção exata do "outro" que se deseja afastar no presente sob o ponto de vista político:

Como os [jesuítas] do Brasil, organizavam também os padres do Paraguai procissões e festas populares. Os índios representavam dramas religiosos, acendiam enormes fogueiras na praça, à roda da qual dançavam, divertiam-se em batalhas simuladas e mais distrações que inventavam.

Assim esse sonho de perfeição, que é irrealizável pelo socialismo ímpio de nossos dias, e que consiste na igualdade dos cidadãos e na comunidade dos bens, realizaram-no os jesuítas inspirados pelo Evangelho. (SERRANO, 1931, p. 198). ${ }^{8}$

7 O uso do "se" no contar da história - hoje chamaríamos de momento contrafactual - pode aqui ser considerado uma intrusão, posto que os verbos empregados são dominantemente o pretérito (perfeito, imperfeito, mais-queperfeito) e o presente histórico - este serve para realçar a seqüência de eventos de uma batalha, uma insurreição, a parte central de uma biografia. $\mathrm{O}$ "se" é uma intrusão reveladora do seu presente e do ponto de vista que gostaria de ver reproduzido no futuro do leitor.

8 Serrano não indica a fonte. A bibliografia sugerida para esse capítulo pode revelar o autor: Rocha Pombo, Padre Madureira, Robert Southey, Basílio de Magalhães, Oliveira Lima, Oliveira Martins Carlos Teschauer.

Educ. e Filos., Uberlândia, v. 21, n. 42, p. 251-272, jul./dez. 2007. 
A mesma intenção está declarada nas entrelinhas, quando relata o desfecho da "Questão Beckman":

Acompanhado de sessenta cúmplices, atacou Beckman uma noite, em 1684, S. Luiz, aprisionou o governador interino, as autoridades, civis e militares e organizou uma Junta dos Três Estados (composta de membros das três classes: clero, nobreza e povo). Decretaram a abolição do monopólio e a expulsão dos jesuítas.

Apagados porém, os primeiros entusiasmos que sempre produz um movimento destes, conheceu o povo que as condições não melhoraram com o governo revolucionário e por isso trataram alguns de se submeter ao governo legal. (SERRANO, 1931, p. 210).

E também, quando faz o balanço final sobre o governo de Floriano Peixoto: "Desta luta ingente e pertinaz [para debelar a Revolta da Armada], o vulto de Floriano saiu engrandecido e aureolado. A defesa enérgica do princípio da autoridade salvou o país da anarquia periódica dos pronunciamentos militares." (SERRANO, 1931, p. 475).

Na vulgata histórica de Serrano, após esse balanço sobre a permanência, inovações historiográficas e intrusões, pode-se concluir que os conteúdos de história do Brasil estavam fortemente embebidos de um teor católico, anti-revolucionário e antieconomicista. O que se percebe, enfim, é que ele mantém os grandes traços delineados na sua história do mundo (cf. Serrano, s.d., Epítome de história universal), um compósito de estudos monográficos, transmitindo novas descobertas e narrada sob influxos das filosofias cristã: (Bossuet) e iluminista (Hegel) da história.

Qual o significado desse caráter da vulgata histórica produzida por Jonathas Serrano para os estudos históricos sobre a disciplina escolar? Em primeiro lugar, por mais próximo que possa parecer, 
a história do Brasil de Serrano não representa um retorno à história sagrada. Esta modalidade disciplinar não poderia, por si só, cumprir todas as finalidades requeridas para o ensino de História do seu tempo. O que se pode depreender da análise da vulgata de Serrano é que ele não se propõe a formar somente padres. A construção dos conteúdos arregimenta preocupações pedagógicas stricto sensu. Ele quer respeitar as peculiaridades cognitivas dos alunos (daí a ausência dos grandes conceitos e a opção pelo vultos e episódios notáveis), estimular o interesse e a satisfação dos adolescentes (opção pela narrativa), além de cultivar a idéia de homem e de humanidade (agregando temas como o valor e o destino do homem para o entendimento da continuidade histórica da espécie e fornecendo exemplos de formação moral e patriótica). Assim, ao construir uma pedagogia da história com tal conteúdo, ao mesclar componentes vários em sua vulgata histórica (componente básico da sua pedagogia da história), Serrano está simplesmente inventando a disciplina História que, no início da década de 1930, já não podia limitar-se à história sagrada do final do século XIX, mas também não deveria configurar-se segundo parâmetros do cientificismo materialista (e socialista), advogado por alguns profissionais que ajudaram a formatar a reforma do ensino secundário brasileiro em 1931 (Reforma Francisco Campos). ${ }^{9}$

9 Para o leitor paciente e curioso, não custa passar os olhos nos programas de História do Pedro II do período 1892/1929, comparando-os com o programa de 1931. Kátia Abud (1993) já deu a sua versão sobre os conteúdos históricos da reforma Campos: a história escolar era a história estudada na perspectiva dos conquistadores e dos dominantes, um poderoso instrumento de dominação ideológica. Os agentes eram os heróis nacionais, a periodização, europeizada. A teoria, positivista; a finalidade do ensino, formar o cidadão - representante da classe dominante. A lista de temas a serem estudados era extensa; não havia reflexão aprofundada sobre psicologia da educação, nem liberdade de ação para a escola e para os professores. Abud afirma também que esse quadro foi resultado da visão de história dos homens que saíram vencedores da Revolução de 1930, nada diferente das concepções do grupo deposto: elitista, harmonizadora, sem admitir mudanças na ordem social. Da nossa parte, se o aparecimento de novas palavras no glossário dos programas de história puder significar alguma coisa, somos tendentes a aceitar como muito provável que

Educ. e Filos., Uberlândia, v. 21, n. 42, p. 251-272, jul./dez. 2007. 


\section{REFERÊNCIAS}

ABUD, Kátia Maria. O ensino de história como fator de coesão nacional: os programas de 1931. Revista Brasileira de História, São Paulo, v. 13, n. 25/26, p. 163-174, set. 1992/ago. 1993.

CHERVEL, André. História das disciplinas escolares: reflexões sobre um campo de pesquisa. Teoria E Educação, Porto Alegre, n. 2, p. 177-254, 1990.

FEDERAÇÃO das Academias de Letras do Brasil. Jonathas Serrano (In memoriam). Rio de Janeiro: FALB, [1945].

FREYRE, Gilberto. Casa-grande E senzala: formação da família brasileira sob o regime de economia patriarcal. 14 ed. Recife: Imprensa Oficial, 1966.

HEGEL, Georg Wilhelm Friedrich. Filosofia da história. 2.ed. Brasília: Editora da Universidade de Brasília, 1999.

HOLLANDA, Sérgio Buarque. Raízes do Brasil. Rio de Janeiro: José Olímpio, 1936.

PRADO JÚNIOR, Caio. Evolução política do Brasil: ensaio de interpretação materialista da história brasileira. São Paulo: Revista dos Tribunais, 1933.

RIBEIRO, João. História do Brasil: curso superior. 4. ed. Rio de Janeiro: Francisco Alves; Paris: Aillaud e Alves, 1912.

tais programas tenham sido "contaminados" com ideais materialistas, posto que a expressão luta de classes é empregada fora do contexto romano; o imperialismo é apontado no sentido de ideologia norte-americana, a palavra mesma "ideologia" está presente como adjetivo, a "origem do capitalismo", também pela primeira vez, é alçada à categoria de lição, e a preocupação em abordar os "aspectos" ou o "desenvolvimento" econômico atravessa a experiência de várias épocas e povos selecionados. 
Maria Junqueira Schmidt. LEÃO, Múcio (Org.). Obras de João Ribeiro: crítica. Rio de Janeiro: Academia Brasileira de Letras, 1961. p. 253-256. [Artigos publicados, originalmente, no Jornal do Brasil a 25 fev. 1928 e 23 mar. 1934].

REIS, José Carlos. As identidades do Brasil: de Varnhagen a FHC. 2.ed. Rio de Janeiro: Fundação Getúlio Vargas, 1999.

SERRANO, Jonathas. Metodologia da história na aula primária. Rio de Janeiro: Francisco Alves, 1917.

História do Brasil. Rio de Janeiro: F. Briguiet, 1931.

. Epítome de história do Brasil. Rio de Janeiro: F. Briguiet, 1933.

Epitome de história universal. 24.ed. Rio de Janeiro: Francisco Alves, s.d. 